\title{
Impact of creative accounting on the company value: Empirical study for Slovakia
}

\author{
Eva Adamikova ${ }^{1, *}$, and Iveta Sedlakova ${ }^{2}$ \\ ${ }^{1}$ University of Zilina, Faculty of Operation and Economics of Transport and Communications, \\ Department of Communications, Univerzitna 1, 01026 Zilina, Slovakia \\ ${ }^{2}$ University of Zilina, Faculty of Operation and Economics of Transport and Communications, \\ Department of Economics, Univerzitna 1, 01026 Zilina, Slovakia
}

\begin{abstract}
.
Research background: Procedures and methods for determining the value of a company are different. The purpose of determining the value of the company, what results the company reports and also who performs the valuation has a significant influence on the choice of the method.

Purpose of the article: The determination of the final value of the company is influenced by many factors, economic, technical, specifics of the company and also the date on which the value is calculated and who performs the evaluation.

Methods: In expert practice in determining the value of the company, we work mainly with methods based on property and income principles (asset method, yield method). The basic material for calculating the value of a company is the company's accounting, which, however, can often be influenced. There can be several purposes for distorting accounting information (financial statements). The most common reason is the reduction of the tax base, or artificial improvement of the achieved results. Creative accounting practices significantly affect the structure of the company as well as its financial results.

Findings \& Value added: The main goal of the paper is to quantify a few examples, which will contribute to reducing the economic result. Subsequently, we analyse these interventions how they can affect the resulting general value of the company determined by the expert and whether the expert is able to detect them.
\end{abstract}

Keywords: value of company; creative accounting; valuation; determining the value of the company; methods based on property and income principles

JEL Classification: $M 41 ; G 32$

*Corresponding author: eva.adamikova@fpedas.uniza.sk 


\section{Introduction}

The company is defined differently in the professional literature depending on the fact on which specific part the authors focus. When a company is evaluated as a whole, it is one complex system in which many relationships and ties take place. It is influenced by many factors of external as well as internal environment, therefore, determining the value of a business is an extremely complex process in practice.

Impacts on the value of the company are addressed by many authors, they analyse external and internal factors. One study examines the relationship between the company's environmental responsibility (CEP) and the company's value [1].

Procedures and methods for determining the value of a business are different. The choice of the method is significantly influenced by the reason why the evaluation is performed and at the same time the time when it is performed.

\section{Theoretical definition}

Value is generally defined as the subjective perception of past, present and future benefits that a particular product, service or security brings to a consumer, where price is the result of an agreement between buyer and seller, each pursuing a different goal.

It is necessary to distinguish between the terms value and price, because from the point of view of valuation the value of the company is not the same as the price. The final price at which a business is sold is the result of many factors that significantly affect it, such as psychological factors, time constraints, personal relationships between seller and buyer, skill in negotiating the price, and the like. [2] The International Valuation Standards Committee (IVSC) also distinguishes between the terms value and price and characterizes them as follows - The price expresses the amount requested, offered or paid for the goods or . The value is the same as the market value. The price of a company is the result of a specific transaction made by comparing supply and demand. [3]

The methods and models, especially mathematical ones, used in determining the value are objective, but the fulfilment of the models with specific data is always conditioned by the subjective decision of the person determining the value. For this reason, the resulting value obtained by quantifying the selected model can vary over a wider range.

In connection with this fact, in some legal acts it is necessary and legally established an independent view of the matter by experts in the given field, specifically in the given article we will deal with the view of an expert. [4] Pursuant to the Decree of the Ministry of Justice of the Slovak Republic no. 492/2004 Coll. on the determination of the general value of property, as amended, the experts determine as the most probable estimate of the price at a given place and time the so-called general value of the property, as well as the general value of the company. We also work with this notion of universal value in our study.

In the evaluation process, each expert must follow and in all circumstances apply the basic principles of evaluation and at the same time a neutral and independent evaluation process of the company. In order to draw up the report correctly, the expert must have a complete overview of the documents as well as of the technical matters involved. [5]

In determining the value of a company, it is important that each of the valuation methods takes into account the key factors of the issue. The value of the objectified asset must consider the acquisition cost of the asset concerned, its degree of depreciation, the development of the market prices of the relevant asset components from the time they are acquired to the time of their valuation. Moreover, it must include the cost associated with the establishment, operation and management of a company and its financial structure, i.e., the share of owned and borrowed capital that covers the assets of the company, as well as the deadlines related to the fulfilment of its obligations. An important factor in determining the value of a company 
by the yield principle is the consideration of its future yield, a well-designed business plan that is related to past business development, especially when the company is valued for an unlimited lifetime The maximization of enterprise value is the goal of enterprise financial strategy, and it can analyse the future development of enterprise from the perspective of enterprise value. [6]

In the case of expert work, the choice of the optimal method is influenced by the legal norms governing expert activity. It also depends on the overall property and liability structure of the company, on the revenue potential of the evaluated company, as well as on the content and scope of the submitted documents from the client of the expert opinion.

\section{Methods}

\subsection{The value of the company determined by an expert}

In the current international evaluation industry, the evaluation of enterprise value has developed rapidly. According to foreign publications, there are three basic valuation methods for assessing the value of a company, namely the cost method, the revenue method and the market method. A series of specific evaluation techniques was derived from the development. The most mature and scientific method is the income approach and the most widely used model in the income approach is free cash flow. [7]

In Slovakia, the most used method in professional practice is the asset and income method, or a combined method, which represents a combination of the asset and income method. In this article, we will focus on the method of assets and returns. The fundamental difference can be seen in the valuation of the same company by both methods in terms of the procedures themselves, as these methods are defined. The property value of the company gives a static picture of the value of the company, because it does not take into account the potential of the company, which is usable from the company's point of view in the future. Conversely, the yield method is based on the company's future income.

The asset method is based on the property principle - the value of the company is calculated as the sum of the values of individual parts of the company's assets, from which the value of foreign capital is deducted. Methods based on the property principle work with quantities that are referred to as state quantities. These are methods that capture and express the state of the company's assets and liabilities at a particular point in time.

Liabilities and overall external sources affect not only the indebtedness of the company but also its value. Optimal indebtedness is also directly related to the financial health of the company, which must be assessed especially with the revenue principle of valuation. [8]

The yield method is based on the revenue principle - the value of the company is calculated as the sum of the present value of depletable resources that the company will create in the future and the continuing value (if it is a company with unlimited life) or final value (if it is a company with limited life.) Valuation methods in expert practice are specified in detail in Decree no. 492/2004 Coll. on the determination of the general value of property, as amended.

One of the basic documents in determining the value of a company by experts is the company's accounting. External and internal factors are taken into account in the expert activity, therefore the financial analysis must be prepared, especially in the case of the yield method, in which it is methodically stated. Financial accounting plays an important role in the processing of financial analysis. [9]

The basic goal of the business is considered to be maximizing profit or maximizing the market value of the company. In the case of a joint stock company, this is about maximizing the market price of shares. The company's financial goals significantly affect the company's 
financial management and policy. Revenue streams provide financial stability for business development, companies should create an individual revenue model that ensures their healthy and sustainable growth. [10] Accounting is a scientific discipline that deals with recording real economic changes in society. The intention is to provide a true and fair view of the company's finances. The company, which is obliged to keep accounts, must ensure continuous and true reporting of facts about the state of assets and their movement, the state of liabilities and their movement, differences between assets and liabilities, income, expenses, income, expenses and profit [11] Accounting is an important part of a company's information system. This system differs for individual companies in the degree of sophistication also in terms of design. Each such information system consists of the collection of accounting data and their subsequent classification, adjustment of this data at the end of the accounting period, and finally a summary of data is available for the presentation of the company's results and their publication. [12]

In addition to accounting information, it is necessary to know other information about the company, its intentions, business partners and the like in the work of an expert. One study addressed the question of whether the disclosure of non-financial information could reflect the quality of the company's financial reports or disclosure policy options. The study examines the relationship between corporate social responsibility (CSR) and accounting conservatism. The results reveal the impact of non-financial information on companies' financial policies. These information are also positive for the work of an expert. [13]

\subsection{Creative accounting}

Each company is unique, each has its own specifics and also its own team of managers on which the company's results depend. Some companies try to use management procedures in their activities, they want to achieve business excellence, which is also addressed in the study where the basis for achieving Business Excellence is to respect the core principles of TQM (Total Quality Management). [14] Other companies like to they use creativity and influence their results to achieve their goal.

The value of a company is determined for various purposes, such as sale, non-monetary deposit, merger, obtaining a loan, etc. Depending on this purpose, the company may try to influence this value with various tools within the legal possibilities. These practices may include creative accounting, which stems from accounting theories but records distorted economic changes in the enterprise according to the wishes of several entities.

Creative accounting can be understood as a conscious distortion of economic changes in a company for a predetermined purpose, it can be characterized as a process in which accountants use their knowledge of accounting laws and rules to manipulate the data contained in the accounting books. [15] Many studies deal with creative accounting in practice. Most studies consider this practice to be unethical and should be stopped; others acknowledge that, although it contributes to business failure, loss of investment and the economic crisis, it is a necessary and legitimate course of action. [16]

It is up to the company to use these creative accounting practices. This is data distortion and manipulation and in some cases can be a criminal offense. Distortion of accounting information (financial statements) can have several purposes. The most common reason is a reduction in the tax base, but an unusual case is the artificial improvement of the achieved results. Various groups may be interested in the distortion of the financial statements, for example, employees, management, or investors who are interested in securing and valuing their investments. The management of the company may be interested in presenting the entity in a "better light", for example in front of competitors, the public, banks or in order to prevent transfer prices between related parties and the like. 
Deciding for entrepreneurs is often challenging, they have to consider which investments are positive and which are negative. For example, a company must consider investing in capital and technology and use them in its circumstances. In balance, old capital companies are riskier because the costly introduction of technologies limits their flexibility in upgrading to the latest technology, exposing them more to technological shocks. [17] Firms and companies with high investments are less risky in equilibrium, as they can more easily replace debt financing with equity financing when increasing external equity is more costly. [18] Creative accounting procedures significantly affect the structure of the company, its financial results. The share of own and foreign sources of coverage of the company's assets affects the financial stability of the assessed company. Equity includes the result of profit, which is mostly distorted in accounting. A high share of equity makes a company more stable, if their share is low, then the company is more unstable. If foreign sources are significantly higher, the company is more unstable and this affects the final value of the company determined by an expert.

\section{Study and results}

From our study, several interventions in accounting were quantified, which contributed to the reduction of the economic result. Subsequently, we analyse the above interventions how an expert is able to reveal creativity in accounting and thus ensure the objective value of the company's assets. We will also describe the mentioned interventions as they will significantly affect the final value of the company from the point of view of the methodological procedure of the asset and yield method. We will also consider whether the expert is able to detect these practices in the course of expert work.

The information and background information for the company we work with in the study relates to the company that was the subject of the research during the expert practice. As the expert is bound by confidentiality, the data about the company are adjusted for the needs of our work, but they are based on the real basis of a functioning company on the Slovak market. ABC Company, Ltd. has been operating on the market since 1992 and on the valuation date as of 31 December 2018. According to the monthly report of the premium payer, 19 employees are employed. The analysed company deals with repairs of agricultural and working machines, motor vehicles, sales of agricultural machinery, vehicles, spare parts and accessories for agricultural machinery and transport equipment. They perform warranty and post-warranty service. The Company does not create any reserve or create provisions for receivables. In the monitored year 2018, the business entity achieves a high economic result for the accounting period (in the amount of EUR 134 742) compared to the previous year 2017 (in the amount of EUR 26 581). The interventions to reduce the economic result were the following:

\subsection{Creating a reserve}

The company provides the customer with a guarantee for the goods sold and services provided. There is a risk associated with this that he will have to pay the customer financial compensation for the damage incurred in the event of a failure, malfunction of the equipment and the like. The business entity will therefore create a reserve for complaints and warranty repairs. The investigated company may create a reserve in the amount of $5 \%$ of the total revenues for goods sold and services provided. We calculate the amount of the reserve for complaints and warranty repairs from the amount of goods sold in the amount of EUR 122,913 and services EUR 740,591, which together amount to EUR 863,504. The reserve created from this will be in the amount of EUR 43,175.20. From the tax point of view, this 
type of reserve is not a tax expense, but affects the economic result. However, since it is not a tax expense, it has an effect on the tax return in the form of an attributable item.

\subsection{Creation of a provision for a receivable}

The company issues an invoice in the amount of $€ 4,000$ with VAT, which was due on March 15,2018 . Due to the insolvency of the business partner, we evaluated it as a risk receivable as of December 31, 2018 and decided to create provisions in the full amount of $€ 4,000$.

From the tax point of view, less than 360 days have passed since the due date of the receivable; we cannot include the provision in tax expenses. We will increase the economic result for the calculation of income tax by this amount in the given tax period.

\subsection{Damage to inventory}

At $\mathrm{ABC}$, s.r.o. a loss event occurred in the form of theft, where the stolen inventory in the total value recorded in the accounts in the amount of EUR 34,000 were stolen. The company was insured, but on the basis of the general contractual conditions, the company was awarded compensation in the amount of only EUR 20,000. From the accounting point of view, there was a decrease in inventories of EUR 34,000 in assets, as well as an increase in receivables for the amount of compensation. From the tax point of view, the recognized tax expense is only up to the amount of EUR 20,000 and the remaining amount of EUR 14,000 forms an item that can be added to the corporate income tax base.

\subsection{The results}

After processing all interventions, the profit in the current accounting period was reduced from the amount of EUR 134,742 to the amount of EUR 73,567. At the same time, there was a decrease in current assets, specifically from the total amounts of EUR 483,072 to the amount of EUR 470,739 and an increase in foreign capital from the common amount of EUR 360,092 to the amount of EUR 408,934.

It follows from the above that practical creative accounting can have a significant structure of the company and its profit for the current accounting period. A simple example shows how significant an impact on the company's results can be created by the creation of a reserve, a provision for a receivable and also a loss event on inventories. There are many creative accounting practices and they can affect the final value of a company in various ways, especially if we analyse a large company.

\section{Impact on the value of the company according to the expert}

Let's look at the specific cases we covered in the example to see if an expert is able to detect creative accounting practices during valuation work. Because each method has a different methodological approach, the cases must also be analysed depending on the method.

\subsection{Asset method}

In the equity method, the general value of the company's assets is calculated from the sum of all components of the company's assets minus the general value of foreign capital. Therefore, the value depends on the structure of assets and liabilities in the company.

The company's asset valuation principle represents a static view of the enterprise as a whole while respecting the principle of conservation of substance. It requires the cooperation 
of experts from technical and economic fields, precise organization of the work, provision of documents, property inspections, consultations with the contracting authority, as well as the use of all the skills and expertise of the experts.

Provision for receivables - will be reflected in the financial statements on the assets side of the statement, based on which the resulting net value of receivables will be lower. From an expert point of view, each receivable denominated in the original currency and the amount in which it was issued and when it was issued is examined in detail. The stated initial value of the receivable is further adjusted to a general value by a methodological procedure using the recoverability coefficient. It depends on the documents and information provided to the expert what the resulting general value of the receivable will be. As this is a receivable from 2018, a very serious reason and basis must be provided in order for the value of the receivable to be reduced in comparison with the created provision. On the liabilities side, the value of the provision for receivables will not be reflected, on the liabilities side it will be reflected in the profit or loss, which falls into the own sources of coverage of assets, not into foreign sources.

Damage to inventories - when calculating the general value of assets, this is reflected in current assets on the assets side. The value of stocks quantified by experts determines all the facts concerning specific stocks. The expert must be informed about the inventory control, he must inspect the inventory himself. Study all evidence of damage, reports from the police, insurance companies and the like. Based on all the information and findings, the expert based on the objectification coefficient - which determines the resulting general value. If all documents proving the reality of the loss event, the expert incorporates this event into the total value of the company's assets. The present value of the receivable from the insurance company recalculated the recovery coefficient $\mathrm{kv}=1.00$ with regard to the assumption of its payment from the insurance company. On the liabilities side, the loss event was reflected in value added tax. It can be seen from this that the loss event on inventories affected both the assets and liabilities side, which has an impact on the calculation of the value of the company's assets.

Provisioning - again has an impact on the liabilities side, specifically foreign capital coverage of assets, which reduces the resulting value of the company's assets as a whole or part of the company. From a professional point of view, it is necessary to examine in detail the justification of the creation of the amount of the created reserve, the tax subject must justify and prove its creation. However, it is problematic for an expert not to accept and question the creation of a reserve, because companies are usually able to justify its creation. With the asset method, the impact of the above accounting adjustments leading to a decrease in the value of the company's assets is possible. For a better overview, we following table by group of assets and liabilities shows the balance on the accounts as at 31 December 2018, a summary of the general value of assets and liabilities determined by experts of the relevant departments at 31 December 2018.

The table also contains columns with net value (after creative accounting (CA) practices) and in the last column the general value of asset components is quantified, in case the documents prove to the expert all the facts that were the subject of interventions.

Table 1. The value of the company before and after the intervention in accounting

\begin{tabular}{|l|r|r|r|r|}
\hline Asset and foreign capital & $\begin{array}{c}\text { Net value } \\
\mathbf{3 1 . 1 2 . 2 0 1 8}\end{array}$ & $\begin{array}{c}\text { General value } \\
\text { with VAT }\end{array}$ & $\begin{array}{c}\text { Net value } \\
\text { (CA) }\end{array}$ & $\begin{array}{c}\text { General value with } \\
\text { VAT (CA) }\end{array}$ \\
\hline Tangible fixed assets & 321118,00 & $\mathbf{3 8 6 ~ 3 5 6 , 8 0}$ & 321118,00 & 386356,80 \\
\hline Inventory & 130497,00 & $\mathbf{1 5 6 5 9 6 , 3 9}$ & 102164,00 & 128263,39 \\
\hline Receivables & 360565,00 & $\mathbf{3 1 3 ~ 3 2 1 , 2 5}$ & 376565,00 & 329321,25 \\
\hline Financial assets & $-7990,00$ & $\mathbf{6 4 5 0 , 7 5}$ & $-7990,00$ & 6450,75 \\
\hline
\end{tabular}




\begin{tabular}{|l|r|r|r|r|}
\hline Sum asset & $\mathbf{8 0 4} \mathbf{1 9 0 , 0 0}$ & $\mathbf{8 6 2} \mathbf{7 2 5 , 1 9}$ & $\mathbf{7 9 1} \mathbf{8 5 7 , 0 0}$ & $\mathbf{8 5 0} 392, \mathbf{1 9}$ \\
\hline Reserve & & & 43175,00 & 43175,00 \\
\hline Responsibilities & 189835,00 & 189835,00 & 195502,39 & 195502,39 \\
\hline credit & 170257,00 & 184697,45 & 170257,00 & 184697,45 \\
\hline Sum foreign capital & 360092,00 & $\mathbf{3 7 4 5 3 2 , 4 5}$ & $\mathbf{4 0 8} \mathbf{9 3 4 , 3 9}$ & $\mathbf{4 2 3} \mathbf{3 7 4 , 8 4}$ \\
\hline $\begin{array}{l}\text { Sum asset - Sum foreign } \\
\text { capital }\end{array}$ & $\mathbf{4 4 4} \mathbf{0 9 8 , 0 0}$ & $\mathbf{4 8 8} \mathbf{1 9 2 , 7 4}$ & $\mathbf{3 8 2} \mathbf{9 2 2 , 6 1}$ & $\mathbf{4 2 7} \mathbf{0 1 7 , 3 5}$ \\
\hline $\begin{array}{l}\text { General value of the } \\
\text { company's asset (EUR) }\end{array}$ & & $\mathbf{4 8 8 ~ 1 9 0 ~ E U R}$ & & $\mathbf{4 2 7 ~ 0 2 0 ~ E U R}$ \\
\hline
\end{tabular}

It can be seen from the above example that the general value of a company can be significantly affected by creative accounting practices.

\subsection{Yield method}

In the yield method, the resulting general value of the company's assets determined by discounting the planned yield resources. Pursuant to the Decree of the Ministry of Justice of the Slovak Republic 492/2004 Coll. on the determination of the general value of assets, as amended, is a yield resource defined as a monetary expression of benefit generated mainly from disposable profits, revenues or cash flows from business or parts of the company or its assets, the amount depending on the company's past development, current market position, but above all from its expected development.

In practice, the economic result is often used as a yield resource when calculating the yield method. Therefore, all of the above accounting adjustments may significantly affect the yield method. The basis of the yield method is the overall strategy in the business plan and financial plan of the company, where the future yield resources are predicted. The financial plan must follow the previous development of the company. Therefore, an expert must prepare an extensive economic and financial analysis of past developments and compare whether the business plan and future development of the company follows its historical development. In the case of a well-designed plan supported by credible evidence, the expert works with the submitted data, which may be distorted when calculating the general value of the company. The expert has no reason to question this distortion if it is documented in detail and well justified. In the case of a newly established company without history, it is important to compare it with similar companies in a given place and time.

In the case of a provision for a receivable, its creation will affect the company's costs in the given year in which it is created and thus the economic result. Provisions for a receivable represent temporary, indirect impairment of assets. As the methodological approach to the business method is based not only on the current state of the company, but also takes into account the overall future development of the company, the business plan should include the cancellation of the provision for a receivable if at the time of determining the value of the company is known it is not necessary to create a provision for a receivable (for example, a receivable has been paid), or if the receivable is derecognised (for example, due to a transfer), it is also necessary to adjust the plan by this fact. In the event of a loss event on inventories, from the point of view of the yield method, this will affect the company's profit by increasing costs and thus contribute to a decrease in profit in the current accounting period with which the expert works according to the financial plan. The creation of a reserve may again affect the calculation of the yield method, as the creation of a provision increases the company's costs in the year in which it was created. In the case of a reserve, the expert must monitor whether further developments with the reserve are included in the financial plan. 
Adjustment of accounting data in order to distort the profit or loss may have a significant effect on the resulting value of the company determined by the yield principle. All the more so as the yield method is calculated from two phases, namely from the present value of the predicted yield resources, mostly calculated for 5 years into the future and from the continuing value, when the unlimited life of the company is expected. The value is particularly risky, as it is very sensitive to the data used in its calculation and can very significantly affect the final general value of the company's assets.

This method is sensitive to a number of influences, not only to creative accounting practices. It is difficult to define the yield resource during in future period, the amount of the interest rate, the sustainable growth rate of the yield resource, the reality of the planned development, cost of equity. Here it is possible to emphasize the usability of accounting variables in order to determine the value of the Beta coefficient. This has a significant impact on the company's revenue value. Therefore, it is not possible to quantify all possible alternatives to selected creative accounting interventions in our paper. The results of our study are easier to prove on the asset method.

\section{Conclusion}

Using a simplified example, we have shown that creative accounting can significantly affect the resulting overall value of a business. Expert activity is particularly demanding for all the specifics of the various cases that the expert will encounter during the evaluation process. The extent to which an expert can detect interventions in accounting always depends on the type of accountant's operation, the quality of the documents submitted and, in particular, his experience and expertise. At the same time, expert activity belongs to knowledge-intensive market services. [19] There are several methods by which creative accounting can be prevented. Misleading financial reporting has a negative impact on all stakeholders because financial records are the primary source of information about the financial stability, economic activity and financial health of any company. [20] There are several ways to avoid misrepresentation of accounting information. When detecting creative accounting and possibly other errors in accounting in the work of an expert, a quality financial analysis helps, which can serve as the primary tool for detecting non-standard deviations. The manipulation of the various accounting items that are included in the calculation of selected indicators can then be reflected in the resulting values of these indicators. These then deviate from the expected development and are identified as non-standard. Of course, these deviations may have a common explanation related to the specifics of the business or changes in the market environment, but they may also be the result of deliberate manipulation. Various statistical techniques and artificial intelligence also focus on fraud detection - Data pre-processing techniques for detecting, validating, correcting errors and filling in missing or incorrect data. $[21,22]$ Experts in economic expert disciplines do not have any programs, resp. software tools to help speed up and streamline calculations and procedures for determining the value of the company as a whole. The valuation methodology of the company must respect and take into account not only the development of the management of the company itself recorded in its financial statements, but also other specific effects of economic development. Because the whole valuation process is affected by many factors, the automation of these processes for determining the value of a company's assets is not yet officially in place in any country.

VEGA 1/0152/18 Business models and platforms in the digital environment. 


\section{References}

1. Gu, W. T., Zhou, S. M., Dong, Z. (2017). Does CEP Influence Corporate Value? Evidence from Chinese Manufacturing Enterprise. Journal of advanced computational intelligence and intelligent informatics, 21(6), 1102-1110.

2. Kislingerová, E. (2001). Business valuation. Praha: C. H. Beck.

3. International Valuation Standards Committee (2000). International Valuation Standards 2000. Pennsylvania State University.

4. Act no. 382/2004 on experts, interpreters and translators, as amended. Retrieved from : https://www.slov-lex.sk/pravne-predpisy/SK/ZZ/2004/382/

5. Szilágyi, M., Sedláková, I. (2002). Economic and legal aspects of determining the general value of a company. University of Zilina.

6. Na, W., Qian, R. (2017). Enterprise Value Evaluation: Application and Improvement based on Cash Flow Model and Economic Value Added Model. In Y. Huo \& Z. Cheng (Eds.), Proceedings of the 2017 International Conference on Humanities Science, Management and Education Technology (HSMET 2017) (pp. 2352-5398). Taiyuan. Atlantis Press.

7. Dong, Y. Q. (2018). Enterprise Value Evaluation Based on FCFF Model - A Case Analysis of Beixinyuan Company. In L. Liu, G. Ke \& H. Davis (Eds.), Proceedings of the 2nd International Conference on Economics and Management, Education, Humanities and Social Sciences (EMEHSS 2018) (pp. 615-620). Wuhan. Atlantis Press.

8. Bartošová, V. (2016). Optimal debt level as part of enterprise financial health prediction. International journal of applied business and economic research, 14(6), 3799-3806.

9. Bartošová, V. (2017). The role of financial business accounting and its changes in managing financial analysis under Slovak conditions. International journal of applied business and economic research, 15(3), 119-126.

10. Remenova, K, Kintler, J, Jankelova, N. (2020). The General Concept of the Revenue Model for Sustainability Growth. Sustainability, 12(16), 6635.

11. Act no. 431/2002 Coll. on accounting as amended. Retrieved from : https://www.slovlex.sk/pravne-predpisy/SK/ZZ/2002/431/20060101.html

12. Čorejová, T., Strenitzerová, M., Madleňáková, L., Majerčáková, M., Jankalová, M. (2010). Network economics. Žilina: University of Zilina.

13. Shen, X., Ho, K. C., Yang, L. and Wang, L. F. S. (2020). Corporate social responsibility, market reaction and accounting conservatism. Kybernetes.

14. Jankalova, M., Jankal, R. (2020). How to Characterize Business Excellence and Determine the Relation between Business Excellence and Sustainability. Sustainability, 12(15), 6198.

15. Jankalova, M. (2013). Conceptions Based on Definition of Business Factors of Successfulness for the Support of Reaching the Excellence of Enterprise Subjects. In U, $\mathrm{Al}$ (Ed.), 1st World Congress on Administrative and Political Sciences (ADPOL) (pp. 531-535). Antalya.

16. Akpanuko, E. E., Umoren, N. J. (2018). The influence of creative accounting on the credibility of accounting reports. Journal of Financial Reporting and Accounting, 16(2), 292-310.

17. Lin, X. J., Palazzo, B., Yang, F. (2020). The risks of old capital age: Asset pricing implications of technology adoption. Journal of monetary economics, 115, 45-161. 
18. Belo, F., Lin, X. J., Yang, F. (2019). External Equity Financing Shocks, Financial Flows, and Asset Prices. Review of financial studies, 32(9), 3500-3543.

19. Majdúchová, H., Rybárová, D., Siváková, B. (2016). Testing of own accounting model on a selected sample of companies in the pharmaceutical and steel industry in the Slovak Republic. Economics and Management, 13(1), 18-30.

20. Corejova, T., Al Kassiri, M. (2015). The Power of Knowledge-Intensive Services. In G. Lee \& G. Schaefer (Eds.), 4th International Conference on Social Sciences and Society (ICSSS 2015) (pp. 354-357). Paris.

21. Svabova, L., Kramarova, K., Chutka, J., Strakova, L. (2020). Detecting earnings manipulation and fraudulent financial reporting in Slovakia. Oeconomia Copernicana, 11(3), 485-508.

22. Klieštik T. et al. (2019). Prediction of the financial health of enterprises in transition economies. Zilina: EDIS - ZU publishing center. 